\title{
Analysis of the Effect of Gross Regional Domestic Product, Total Population, Exchange Rate, and Interest Rate on Tax Revenue in North Sumatra Province
}

\author{
Nazlia Wibowo ${ }^{1}$, HB Tarmizi ${ }^{2}$, Rahmanta $^{3}$ \\ ${ }^{1,2,3}$ Faculty of Economics and Business, Universitas Sumatera Utara, Indonesia \\ Corresponding Author: Nazlia Wibowo
}

\begin{abstract}
This study aims to determine and analyze of the effect of gross regional domestic product, total population, exchange rate, and interest rate on tax revenue in North Sumatra Province. This study uses secondary data with panel data type which is a combination of time series data and cross section data. The time series data is the period from 2015 to 2020, while the cross section data in this study contains 11 working area of the Directorate General of Taxes of Indonesia, North Sumatra Province. By using the EViews 11 software. The results showed that simultaneously the variables of gross regional domestic product, total population, exchange rate, and interest rate on tax revenue in North Sumatra Province. Partially, gross regional domestic product has a positive and significant effect on tax revenue, population has a positive but not significant effect on tax revenue, exchange rate has a negative and significant effect on tax revenue, and interest rate has a positive but not significant effect on tax revenue in North Sumatra Province.
\end{abstract}

Keywords: Gross Regional Domestic Product, Total Population, Exchange Rate, Interest Rate, Tax Revenue

\section{INTRODUCTION}

Tax is a mandatory levy from the people for the state. Every Rupiah paid by the people will become state income from the tax sector. The function of collecting taxes is to finance central and regional government spending in order to achieve people's welfare. Taxes are a source of government funds to fund central and regional development, such as building public facilities, budgeting for health and education, and other productive activities. Tax collection can be forced because it is carried out by law. In Indonesia, taxes are used as the main source of state revenue. By law, taxes are defined as mandatory contributions to the government that are coercive and legal, so that the government has legal power (fines) to take action on taxpayers who do not fulfill their obligations.

In essence, taxes are a means for the welfare of the people. This belief in the welfare of the people can be realized when the government is able to collect taxes from citizens and use it to build the nation and state of Indonesia. In Indonesia, more than $80 \%$ of the Republic of Indonesia's revenue comes from taxes. Normally, a good state expenditure budget is the main revenue from taxes, because one of the functions of taxes is a stability function (Ulin, 2019).

According to Haniz and Sasana (2014) Indonesia's economic potential is different in each region, so that more equitable development is needed in each region to deal with this situation. The implementation of regional autonomy, which focuses on each district and city, begins with the transfer of various 
Nazlia Wibowo et.al. Analysis of the effect of gross regional domestic product, total population, exchange rate, and interest rate on tax revenue in North Sumatra Province.

authorities from the central government to the local government concerned. The transfer of this authority must be accompanied by the delivery and transfer of financing. Each regency and city is given financial resources to finance its own expenses so as not to depend on the central or provincial government.

The Directorate General of Taxes has certainly made maximum efforts so that tax revenues are realized in accordance with the set targets. However, in reality, tax revenue in North Sumatra Province has not yet reached the target set by the Directorate General of Taxes in North Sumatra Province. From the existing data, although it tends to increase every year the realization of tax revenue in North Sumatra Province has not $100 \%$ reached the target set by the Directorate General of Taxes of North Sumatra Province. As in 2015, the achievement was only $80.20 \%$, with a target of Rp23,285,235,795,003 tax revenues obtained of Rp18,673,624,805,051. In 2017 the realization of tax revenue was Rp21,536,874,037,934 with a target of Rp23,939.051,915,996. The Directorate General of Taxes succeeded in increasing the achievement of tax realization by 89.97\%. Then in 2020 the Directorate General of Taxes reduced the tax revenue target, which was Rp21,717,878,321,000. This decrease in target was due to the phenomenon of COVID-19 which resulted in decreased economic growth. The achievement of tax revenue in 2020 is $99.73 \%$. Of course, both the North Sumatra Province Directorate General of Taxes 1 and the North Sumatra Province Directorate General of Taxes 2 have done their best so that tax revenues are realized in accordance with the set targets. The achievement of tax revenue is influenced by factors that can increase the realization of tax revenue in North Sumatra Province. The increase in gross regional domestic product cannot be separated from the impact of increased economic activity. The high economic growth can be seen from the value of the gross domestic product in the area. If economic growth increases, people's income and welfare will also increase. The increase in people's income can increase public consumption in paying taxes (Nurrohman, 2010).

Another factor that affects tax revenue is the population. The population has an effect on tax revenue, because the more the population, the higher production will be in order to meet the needs for goods and services from the population itself, which will have an impact on tax revenue (Hanifa, 2017).

The exchange rate is also a factor that can affect North Sumatra Province tax revenue. According to Nurfitri et al (2020) when the exchange rate weakens, the industrial sector that relies on imports of raw materials and capital goods will experience a reduction in production results due to high production costs. Reduction in production results will cause a decrease in sales so that it will reduce income that is subject to tax. This will cause tax revenue will be reduced.

The macroeconomic factor that also affects tax revenue is the interest rate. Changes in interest rates have two effects, namely the substitution effect and the income effect. The substitution effect for an increase in the interest rate is that households tend to reduce consumption spending and increase savings. Meanwhile, the income effect for an increase in interest rates is an increase in consumption spending and a decrease in savings. Both of these effects can affect people's consumption patterns where consumption will affect value added tax receipts (Aliviyanto, 2017).

This study aims to determine and analyze of the effect of gross regional domestic product, total population, exchange rate, and interest rate on tax revenue in North Sumatra Province.

\section{RESEARCH METHODS}

This study uses secondary data with panel data type which is a combination of time series data and cross section data, effect of one or more predictor variables on 
Nazlia Wibowo et.al. Analysis of the effect of gross regional domestic product, total population, exchange rate, and interest rate on tax revenue in North Sumatra Province.

the response variable (Pandiangan et al., 2021). The time series data is the period from 2015 to 2020, while the cross section data in this study contains 11 working area of the Directorate General of Taxes of Indonesia, North Sumatra Province.

This research uses panel data regression analysis technique. Data Panel Regression is a combination of cross section data and time series, where the same unit cross section is measured at different times. So, in other words, panel data is data from some of the same individuals observed in a certain period of time (Tobing et al., 2018). Time series data is data from one object with certain time periods (Pandiangan, 2015). Cross section data is data obtained from one or more research objects in the same period (Pandiangan, 2018).

Panel fund regression using partial significance test (t test) and simultaneous significance test ( $\mathrm{F}$ test). The $\mathrm{F}$ test is to find out whether all the independent variables in the study have a significant effect on the dependent variable simultaneously. $t$ test is to determine the significance or significance of the influence of each independent variable (Pandiangan et al., 2018). Panel data regression analysis by using the EViews 11 software.

\section{RESULT}

\section{Development of Tax Revenue Realization in North Sumatra Province}

Tax revenue is the main source of state revenue which functions to fund central and regional development such as building public facilities, budgeting for education and health, as well as other productive activities. The duties and functions of tax revenue are carried out by the Directorate General of Taxes (DJP) under the Ministry of Finance of the Republic of Indonesia. When the government is able to collect taxes from citizens and use it to build the nation and state of Indonesia, then this trust for the welfare of the people can be realized. Under normal circumstances, a good state expenditure budget is its main revenue from taxes, because one of the functions of taxes is a stability function.

Tax revenues managed by the DJP include: income tax $(\mathrm{PPh})$, value added tax $(\mathrm{PPN})$, luxury goods sales tax (PPnBM), stamp duty, and land and building tax (PBB). The office of the DJP in North Sumatra Province is divided into two regional offices, namely the regional offices of the DJP North Sumatra Province 1 and the DJP North Sumatra Province 2. The regional offices of the DJP North Sumatra Province 1 include the Tax Service Office (KPP) Pratama Medan Barat, KPP Pratama Medan Belawan, KPP Pratama Medan Kota, KPP Pratama Medan Petisah, KPP Pratama Medan Polonia, KPP Pratama Medan Timur which in this study became the Medan area, KPP Pratama Madya Medan, KPP Pratama Binjai, and KPP Pratama Lubuk Pakam. However, KPP Pratama Madya Medan was not included in this study because the object of the taxpayer is spread across several areas in North Sumatra Province.

The regional offices of DJP Sumut 2 include KPP Pratama Tebing Tinggi, KPP Pratama Kisaran, KPP Pratama Rantau Prapat, KPP Pratama Pematang Siantar, KPP Pratama Padang Sidempuan, KPP Pratama Sibolga, KPP Pratama Balige, and KPP Pratama Kabanjahe.

Based on the data, during the 2015 to 2020 period, tax receipts at each DJP North Sumatra Province office, both DJP 1 and DJP 2, have different fluctuation patterns. At KPP Pratama Medan, it can be seen that tax revenue tends to decrease while at KPP Pratama Binjai and Padang Sidempuan tends to increase. In 2019, the largest tax revenue was in the city of Medan, which was Rp5,724,020,542,860 in second and third place were KPP Pratama Lubuk Pakam and KPP Pratama Padang Sidempuan, which amounted to Rp1,415,962,785,022 and Rp1,051,055,147,389, respectively. while the smallest tax revenues in 2019 were KPP Pratama Kabanjahe, KPP Pratama Tebing Tinggi, and KPP Pratama Balige with tax revenues of Rp268,990,530,351, 
Nazlia Wibowo et.al. Analysis of the effect of gross regional domestic product, total population, exchange rate, and interest rate on tax revenue in North Sumatra Province.

Rp419,565,800,546, and Rp453,555,660,741 respectively. Then in 2020 the average tax revenue at each KPP Pratama decreased from the previous year such as KPP Pratama Medan and KPP Pratama Lubuk Pakam although it was still the largest tax revenue KPP but decreased from the previous year, which was Rp4,444,352,121,293 and
Rp1,262,793.659,368, in contrast to KPP Pratama Padang Sidempuan whose tax revenue increased from the previous year, which was Rp1,051,055,147,389. The smallest tax revenues in 2020 were at KPP Pratama Kabanjahe, KPP Pratama Tebing Tinggi, and KPP Pratama Balige whose tax revenues decreased from the previous year.

\section{Panel Data Regression Analysis}

Table 1. Estimation Results of Panel Data Regression Model (REM)

Dependent Variable: LOG_PAJAK?

Method: Pooled EGLS (Cross-section random effects)

Date: 07/30/21 Time: 15:30

Sample: 20152020

Included observations: 6

Cross-sections included: 11

Total pool (balanced) observations: 66

Swamy and Arora estimator of component variances

\begin{tabular}{|c|c|c|c|c|}
\hline Variable & Coefficient & Std. Error & $\mathrm{t}$-Statistik & Prob. \\
\hline $\mathrm{C}$ & 10.40711 & 2.804997 & 3.710203 & 0.0004 \\
\hline LOG PDRB? & 1.141404 & 0.232022 & 4.919388 & 0.0000 \\
\hline LOG_PDDK? & 0.376147 & 0.388166 & 0.969035 & 0.3364 \\
\hline LOG_KURS? & -1.465936 & 0.528203 & -2.775326 & 0.0073 \\
\hline SUKU_BUNGA? & 0.006894 & 0.006051 & 1.139390 & 0.2590 \\
\hline \multicolumn{5}{|l|}{ Random Effects (Cross) } \\
\hline _MEDAN--C & 0.141110 & & & \\
\hline BINJAI--C & -0.081649 & & & \\
\hline LUBUK PAKAM--C & -0.069928 & & & \\
\hline _TEBING_TINGGI--C & 0.061439 & & & \\
\hline KISARAN--C & -0.152290 & & & \\
\hline RANTAU_PRAPAT--C & -0.065699 & & & \\
\hline PEMATANG_SIANTAR--C & 0.061771 & & & \\
\hline PADANG_SIDEMPUAN--C & 0.066963 & & & \\
\hline SIB̄OLGA--C & 0.007779 & & & \\
\hline BALIGE--C & 0.146966 & & & \\
\hline \multirow[t]{3}{*}{ KABANJAHE--C } & -0.116463 & & & \\
\hline & \multirow{2}{*}{\multicolumn{2}{|c|}{ Effects Specification }} & & \\
\hline & & & S.D. & Rho \\
\hline Cross-section random & & & 0.116810 & 0.8118 \\
\hline Idiosyncratic random & & & 0.056234 & 0.1882 \\
\hline
\end{tabular}

\begin{tabular}{llll}
\hline & Weighted Statistiks & \\
\hline R-squared & 0.628244 & Mean dependent var & 2.290759 \\
Adjusted R-squared & 0.603866 & S.D. dependent var & 0.088075 \\
S.E. of regression & 0.055434 & Sum squared resid & 0.187447 \\
F-statistik & 25.77148 & Durbin-Watson stat & 1.753157 \\
Prob(F-statistik) & 0.000000 & & \\
\hline \hline
\end{tabular}

Source: Eviews 11 Software Processing Results

The results showed that simultaneously the variables of gross regional domestic product, total population, exchange rate, and interest rate on tax revenue in North Sumatra Province.

Partially, gross regional domestic product has a positive and significant effect on tax revenue, population has a positive but not significant effect on tax revenue, exchange rate has a negative and significant effect on tax revenue, and interest rate has a positive but not significant effect on tax revenue in North Sumatra Province. 
Nazlia Wibowo et.al. Analysis of the effect of gross regional domestic product, total population, exchange rate, and interest rate on tax revenue in North Sumatra Province.

\section{CONCLUSION AND SUGGESTION}

The results showed that simultaneously the variables of gross regional domestic product, total population, exchange rate, and interest rate on tax revenue in North Sumatra Province. Partially, gross regional domestic product has a positive and significant effect on tax revenue, population has a positive but not significant effect on tax revenue, exchange rate has a negative and significant effect on tax revenue, and interest rate has a positive but not significant effect on tax revenue in North Sumatra Province.

Based on the conclusions that have been stated above, the suggestions that can be given by researchers are as follows:

1. The Directorate General of Taxes as the party that has the authority to implement and realize tax revenue targets in order to realize tax revenues in accordance with the targets set by paying attention to the factors that affect tax revenues in the North Sumatra Province.

2. For further researchers who want to improve this research, it is expected to add variables that if they affect the realization of tax revenues, for example the population variable in this study is changed to labor/working age population and involves more research data such as inflation, exports, imports, rates of consumption, society so that the research results obtained become more valid.

\section{Acknowledgement: None}

\section{Conflict of Interest: None}

\section{Source of Funding: None}

\section{REFERENCES}

1. Aliviyanto, H. A. (2017). Pengaruh Inflasi dan Tingkat Suku Bunga Terhadap Penerimaan Pajak Pertambahan Nilai. Malang: Fakultas Ilmu Administrasi Universitas Brawijaya.

2. Hanifa, N. (2017). Analisis Determinan Penerimaan Pajak di Indonesia. Medan:
Fakultas Ekonomi dan Bisnis Universitas Sumatera Utara.

3. Haniz, N. F., \& Sasana, H. (2014). Analisis Faktor-faktor yang Mempengaruhi Penerimaan Pajak Daerah Kota Tegal. Diponegoro Journal of Economics, 3(1).

4. Nurfitri., Zakaria, J., Arfah, A. (2020). Pengaruh Nilai Tukar Rupiah, Suku Bunga dan Tingkat Inflasi Terhadap Penerimaan Pajak di Kota Makassar. Paradoks: Jurnal Ilmu Ekonomi, 3(1).

5. Nurrohman, A. (2010). Analisis Faktorfaktor yang Mempengaruhi Penerimaan Pajak Daerah di Kota Surakarta (Tahun 1994-2007). Surakarta: Fakultas Ekonomi Universitas Sebelas Maret.

6. Pandiangan, Saut Maruli Tua. (2015). Analisis Lama Mencari Kerja Bagi Tenaga Kerja Terdidik di Kota Medan. Skripsi. Medan: Fakultas Ekonomi dan Bisnis, Program Studi Ekonomi Pembangunan, Universitas Sumatera Utara. https://www.academia.edu/52494724/Analis is_Lama_Mencari_Kerja_Bagi_Tenaga_Ker ja_Terdidik_di_Kota_Medan.

7. Pandiangan, Saut Maruli Tua. (2018). Analisis Faktor-faktor yang Mempengaruhi Penawaran Tenaga Kerja Lanjut Usia di Kota Medan. Tesis. Medan: Fakultas Ekonomi dan Bisnis, Program Studi Ilmu Ekonomi, Universitas Sumatera Utara. http://repositori.usu.ac.id/bitstream/handle/1 23456789/10033/167018013.pdf?sequence $=$ 1\&isAllowed $=\mathrm{y}$.

8. Pandiangan, Saut Maruli Tua, Rujiman, Rahmanta, Tanjung, Indra I., Darus, Muhammad Dhio, \& Ismawan, Agus. (2018). An Analysis on the Factors which Influence Offering the Elderly as Workers in Medan. IOSR Journal of Humanities and Social Science (IOSR-JHSS), 23(10), 76-79. DOI: 10.9790/0837-2310087679.

9. Pandiangan, Saut Maruli Tua, Resmawa, Ira Ningrum, Simanjuntak, Owen De Pinto, Sitompul, Pretty Naomi, \& Jefri, Riny. (2021). Effect of E-Satisfaction on Repurchase Intention in Shopee User Students. Budapest International Research and Critics Institute-Journal, 4(4), 77857791.

DOI: https://doi.org/10.33258/birci.v4i4.2697.

10. Tobing, Murniati, Afifuddin, Sya'ad, Rahmanta, Huber, Sandra Rouli, Pandiangan, Saut Maruli Tua, \& Muda, Iskandar. (2018). An Analysis on the 
Nazlia Wibowo et.al. Analysis of the effect of gross regional domestic product, total population, exchange rate, and interest rate on tax revenue in North Sumatra Province.

Factors Which Influence the Earnings of Micro and Small Business: Case at Blacksmith Metal Industry. Academic Journal of Economic Studies, 5(1), 17-23. https://www.ceeol.com/search/articledetail?id=754945.

11. Ulin, Muhammad. (2019). Pajak dan Pembangunan Nasional. Online. https://www.pajak.go.id/artikel/pajak-danpembangunan-nasional.
How to cite this article: Nazlia Wibowo, HB Tarmizi, Rahmanta. Analysis of the effect of gross regional domestic product, total population, exchange rate, and interest rate on tax revenue in North Sumatra Province. International Journal of Research and Review. 2021; 8(12): 657-662.

DOI: https://doi.org/10. 52403/ijrr.20211281 